\title{
TINJAUAN KRITIS PANDANGAN HARFIAH HARI PENCIPTAAN
}

\author{
Jack David Kawira \\ Gereja Reformed Injili Indonesia Semarang
}

\begin{abstract}
ABSTRAK: Pemahaman terhadap hari penciptaan di dalam Kejadian 1:1-2:3 telah menuai begitu banyak perdebatan dan argumentasi. Oleh karena itu, studi narasi penciptaan di dalam Kejadian 1:1-2:3 menjadi hal yang sangat penting untuk dapat melihat kembali kekonsistenan penafsiran harfiah terhadap narasi penciptaan di dalam Alkitab. Penafsiran harfiah yang dimaksud adalah penafsiran yang melihat bahwa penciptaan benar-benar terjadi dalam durasi waktu 6 hari normal dengan mengikuti urutan kronologis yang dinyatakan dalam narasi penciptaan mulai dari hari pertama hingga hari keenam, dimana pada hari ketujuh Tuhan memberkati dan menguduskannya, dan yang menjadikan hari ketujuh memiliki aspek harfiah dan tidak harfiah. Selain itu, dengan menyadari banyaknya tantangan dan kritik terhadap penafsiran harfiah, baik dari pendekatan penafsiran tidak harfiah maupun pendekatan ilmu pengetahuan modern, maka pembahasan akan tantangan dan kritik tersebut menjadi sangat penting agar pembahasan penafsiran harfiah menjadi kian limpah.
\end{abstract}

KATA KUNCI: Hari penciptaan, harfiah, kronologis, tidak harfiah, ilmu pengetahuan modern.

ABSTRACT: The understanding towards the days of creation in Genesis 1:1-2:3 has reaped so much debates and argumentations. Because of that, the study on account of Creation in Genesis 1:1-2:3 become very important in order to see the consistency of literal interpretation towards creation narratives in the Bible. The meaning of literal interpretation is the 
interpretation which see that the creation account happened within six normal days duration in a chronological order which showed by the creation narratives; it starts from the first day to the sixth day, and in the seventh day, God bless and sanctify it, and it makes the seventh day has literal and nonliteral aspect. Besides that, by realizing the challenges and critics towards literal interpretation, either from non-literal interpretation or from modern science approach, the discussion about these challenges and critics becomes very important in order to achieve the fruitful discussion on literal interpretation.

KEYWORDS: Days of Creation, literal, chronological, non-literal, modern science.

\section{Latar Belakang Sejarah Penafsiran Harfiah}

Pandangan harfiah hari penciptaan meyakini bahwa Tuhan menciptakan alam semesta dalam urutan kronologis selama 6 hari, yang dimengerti oleh manusia sebagai 24 jam dalam satu hari. Sehingga penciptaan terjadi dalam rentang waktu $6 \times 24$ jam. ${ }^{1}$ Pandangan mengenai hari harfiah di sepanjang sejarah mula-mula hingga jaman Reformasi tidak terdapat banyak perbedaan yang signifikan, maupun kesulitan untuk menerima bahwa Allah yang berkuasa dan berdaulat menciptakan alam semesta di dalam 6 hari harfiah. Memang terdapat beberapa tokoh yang memiliki pandangan tidak harfiah sebelum adanya tantangan yang diberikan oleh ilmu pengetahuan modern yang menyatakan bahwa usia bumi sudah begitu tua, namun tidak begitu banyak dibandingkan dengan saat ini di mana ilmu pengetahuan modern begitu besar peranannya di dalam penafsiran akan hari penciptaan.

\footnotetext{
1 Pengertian waktu dalam pembagian sexagesimal baru muncul +/-2000 SM di Babilonia. Akan tetapi penulis tetap menggunakan terminologi 24 jam untuk menekankan hari normal/ordinary days.
} 
Tokoh kunci dalam kepercayaan Yudaisme, diwakili oleh pandangan Ibn Ezra dan Mimonides memegang dengan kuat iman bahwa proses penciptaan yang dikerjakan oleh Allah benar-benar selama 6 hari x 24 jam. $^{2}$ Meskipun Philo dari Alexandria (20 SM - 50 M) memilih untuk menafsirkan bagian tersebut secara figuratif, hal ini dapat dimengerti karena ia termasuk dari kalangan Yahudi Helenistik dan ia menggunakan pendekatan alegoris untuk mencampur dan mengharmonisasikan antara filsafat Yunani dengan Yudaisme. $^{3}$

Pandangan penafsiran secara harfiah diyakini pula di antara Bapa Gereja mula-mula kecuali Clement dari Alexandria (150-215), Origen (185253) dan Agustinus (354-430). Hal ini disebabkan karena ketiganya berasal dari aliran Alexandria, dan memiliki tendensi untuk mengalegorikan beberapa bagian dari Alkitab. Penafsiran alegoris tersebut juga tidaklah berasal dari teks Alkitab, melainkan dari luar yang merupakan pengaruh dari pemikiran Yunani. Dalam banyak kasus mereka justru mengatakan bahwa Tuhan menciptakan segala sesuatu secara instan dan bukan dalam periode waktu yang lama. ${ }^{4}$ Alternatif penafsiran eksegesis dari Agustinus justru secara konsisten dipelajari di dalam rasa hormat dan tidak pernah dipandang sebagai ajaran sesat. ${ }^{5}$ Karena itu, penafsiran tidak harfiah tidaklah selalu dapat diidentikan dengan orang-orang heterodox, yang bahkan tidak percaya bahwa Adam dan Hawa benar-benar tokoh historis.

Di sisi yang lain, Seraphim Rose dari aliran Ortodoks Timur dengan teliti mengkaji pandangan dari Bapa-Bapa Gereja Ortodoks Timur yang melihat bahwa penafsiran mereka akan narasi penciptaan sama seperti

\footnotetext{
2 Paul James Griffiths, Creation days and Orthodox Jewish Tradition, diakses 9 Juni 2015, http://creation.com/ creation-days-and-orthodox-jewish-tradition.

3 Justin Marson, "Jewish understanding of Genesis 1 to 3," Science E Christian Belief, Vol. 12, No. 2 (2000): 130.

4 Robert M. Gurney, Six-Day Creation: Does It Matter What You Believe?, Wise Choices (Leominster England: Day One Publications, 2007), 15.

5 Herman Bavinck, Reformed Dogmatics: God and Creation (Grand Rapids: Baker, 2003- 2008), 483.
} 
modern creationists. Mereka setuju di dalam peristiwa penciptaan di dalam seminggu, kejatuhan dan peristiwa air bah yang terjadi secara global. Mereka sangat percaya bahwa tindakan penciptaan Allah adalah suatu tindakan yang terjadi secara instan, dan mereka juga melihat bahwa dunia sebelum jatuh secara fundamental berbeda dengan dunia setelah kejatuhan. ${ }^{6}$ Pandangan ini sejalan dengan yang diimani oleh tokoh-tokoh Reformasi seperti Luther dan Calvin. ${ }^{7}$ Dengan demikian kita dapat melihat pandangan penafsiran secara harfiah telah memiliki tradisi yang begitu kuat di dalam sejarah.

Namun, tentu saja terdapat kesulitan yang begitu besar karena sejarah penafsiran tersebut belum berhadapan dengan fakta-fakta di dalam modern science, seperti penelitian usia bumi dari menganalisa lapisan tanah, fosil, dan juga pengukuran kecepatan cahaya, di mana semuanya menyatakan usia bumi yang tua. Sehingga saat ini, kemajuan di dalam bidang ilmu pengetahun telah memberikan suatu tantangan yang menyatakan suatu ketidakmungkinan bahwa alam semesta diciptakan di dalam 6 hari secara harfiah. Dan oleh sebab itu, terdapat pula beberapa teolog seperti, Alister McGrath, Davis A.Young dan Benjamin B. Warfield yang mencoba mengatakan jikalau Calvin hidup di masa saat ini pastilah ia tidak akan melihat hari penciptaan sebagai 6 hari yang harfiah. 8 Namun Erik Guicehelaar menyangkal fakta tersebut di dalam artikelnya dengan menyatakan Calvin tetap akan melawan setiap pengertian evolusi di dalam penciptaan karena teori tersebut bertentangan dengan Firman Tuhan itu sendiri. ${ }^{9}$

Perdebatan ini pula yang kemudian memicu terbentuknya beberapa organisasi yang memegang pandangan penafsiran secara harfiah, di

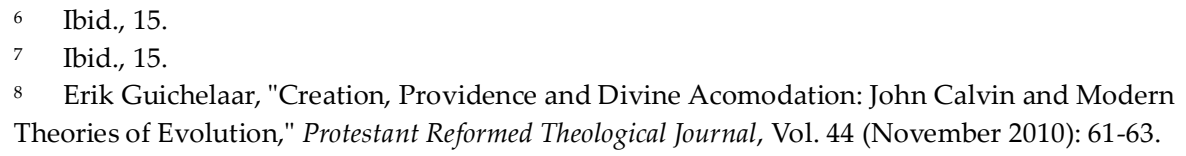


antaranya yang paling besar adalah The Creation Research Society (CRS) didirikan tahun 1963 dan menerbitkan Creation Research Society Quarterly sebagai media penulisan akademik. Selain itu, The Geoscience Research Institute (GRI) didirikan tahun 1958 dan berafiliasi dengan Loma Linda University dan Andrews University. GRI menerbitkan Origins sebagai jurnal akademis. Lalu The Institute for Creation Research (ICR) didirikan tahun 1972 oleh Henry Morris. Di dalam ICR terdapat para ahli yang sangat terkenal yang mendukung pandangan tersebut seperti Duane Gish dan Ken Ham. Selain organisasi tersebut, beberapa organisasi dan perkumpulan yang mendukung pandangan tersebut tersebar di begitu banyak negera seperti Kanada, Australia, Jerman, Inggris dan Korea. ${ }^{10}$

\section{Argumentasi Pandangan Harfiah}

Pandangan tersebut melihat bahwa Tuhan menciptakan alam semesta dalam 6 hari harfiah atau 24 jam dalam satu hari dan berlangsung dalam urutan kronologis mulai dari hari pertama hingga kepada hari yang keenam. Mulai dari proses penciptaan yang lebih sederhana hingga kepada penciptaan manusia sebagai gambar dan rupa Allah. Gurney berpendapat di dalam penelitiannya bahwa sejauh yang ia pahami tidak ada professor Ibrani ataupun dalam Perjanjian Lama di dalam universitas kelas dunia yang tidak percaya bahwa penulis kitab Kejadian 1-11 memang benar-benar mengintensikan untuk menyatakan kepada pembacanya pemikiran bahwa penciptaan memang betul terjadi di dalam 6 hari secara berurutan sebagaimana hari yang kita alami saat ini, dan bahwa tokoh-tokoh yang ada di dalam daftar keturunan di dalam kitab Kejadian secara sederhana menyatakan suatu peristiwa kronologis dari awal dunia hingga di dalam kisah-kisah Alkitab, dan bahwa Air Bah di dalam cerita Nuh dimengerti

\footnotetext{
10 James Porter Moreland and John Mark Reynolds, Three Views On Creation and Evolution, Counterpoints (Grand Rapids: Zondervan, 1999), 42-43.
} 
terjadi di seluruh dunia dan mematikan semua makhluk hidup kecuali yang berada di dalam Bahtera. ${ }^{11}$

\section{Argumentasi Frase Jadilah Petang dan Jadilah Pagi}

Hal yang dapat diamati adalah bahwa setiap hari di dalam penciptaan diikat di dalam kehadiran petang dan pagi. Sesuatu yang penting untuk disadari adalah hari pertama tidaklah terdiri dari kegelapan mula-mula dan kemunculan terang, tetapi dibentuk ketika terang telah diciptakan dengan pergantian pertama dari petang dan pagi. Petang yang pertama bukanlah sesuatu yang muram atau remang-remang, tetapi sangatlah mungkin didahului dengan cahaya yang sangat terang sebagaimana terang keluar dari kegelapan dan terjadi relasi pergantian antara kegelapan dengan terang yang bersinar penuh. Semua hal tersebut terjadi setelah terang diciptakan dan pemisahan antara terang dan gelap terjadi, baru jadilah petang dan jadilah pagi, membentuk satu hari atau hari pertama. ${ }^{12}$ Tentu saja, hari penciptaan tidaklah dimengerti siklusnya dari petang menuju petang ataupun dari pagi kepada pagi, karena hari pertama tidak sepenuhnya berakhir sampai kembalinya cahaya setelah kegelapan malam dan tidak berakhir sampai terbitnya pagi di mana pergantian terang dan gelap selesai. Sehingga pengertian satu hari adalah setelah petang dan pagi datanglah satu hari. Hal ini juga berlandaskan fakta bahwa petang sampai pagi bukanlah satu hari, tetapi akhir dari satu hari. Sehingga hari pertama dimulai pada saat Tuhan membuat terang bersinar dari kegelapan, tetapi terang ini tidak menjadi satu hari sampai petang tiba dan gelap yang berada di antara petang hingga pagi kembali merekah. ${ }^{13}$ Dan apabila kita dapat menyadari hari penciptaan terjadi di dalam regulasi pertukaran terang dan

\footnotetext{
11 Gurney, Six-Day Creation, 11.

12 Carl Friedrich Keil and Franz Delitzsch, Commentary On the Old Testament (Peabody: Hendrickson, 2006), 31.

13 Ibid., 32.
} 
gelap, maka hari dalam penciptaan haruslah dilihat sebagai durasi hari normal dalam dunia, bukan sebagai suatu periode waktu yang tidak dapat dihitung atau melihat durasinya bisa ribuan tahun. ${ }^{14}$

Lebih lanjut, jika kita melihat kata petang disebutkan lebih dahulu sebelum kata pagi mengindikasikan suatu bukti bahwa orang-orang pada saat itu melihat permulaan dari satu hari adalah pagi. Sehingga frase tersebut tidak sedang berbicara penghitungan dari hari melainkan menyatakan waktu "lenggang" sampai bekerja lagi di pagi hari. ${ }^{15}$ Oleh karena itu, sesuai dengan krangka penciptaan di mana Tuhan bekerja menciptakan seluruh alam semesta di dalam 6 hari dan beristirahat pada hari yang ke-7 maka pengulangan kata tersebut hanya muncul pada 6 hari pertama, yakni pada waktu Tuhan sedang melakukan karya penciptaannya, sementara frase tersebut tidak terdapat pada hari ke-7 karena pada hari ke-7 Tuhan beristirahat. Jadi frase tersebut memberikan penekanan pemisahan antara waktu kerja dan istirahat Tuhan pada setiap harinya dan pada hari ke-7 Ia berhenti dari segala karya penciptaan dengan menguduskan dan memberkati hari ke-7 tersebut (Kej. 2:3).

\section{Argumentasi Kata Hari Sebagai Harfiah}

Alkitab secara umum menggunakan kata hari "yom" untuk menyatakan pengertian 24 jam ataupun waktu terang antara rentang waktu selama satu hari. Terlebih ketika kata hari digabung dengan angka, secara universal Alkitab menyatakannya sebagai suatu hari normal di dalam sistem tata surya kita. ${ }^{16}$ Memang terkadang terminologi hari dalam Alkitab tidak menggambarkan suatu periode waktu pasti, seperti apa yang dikatakan oleh

\footnotetext{
$14 \quad$ Ibid., 32.

15 Victor P. Hamilton, The Book of Genesis. Chapters 1-17, The New International Commentary

On the Old Testament (Grand Rapids: Eerdmans, 1990), 121.

16 Douglas F. Kelly, Creation and Change: Genesis 1.1-2.4 in the Light of Changing Scientific Paradigms (Fearn: Mentor, 1997), 107.
} 
Ayub 7:6, Mazmur 90:9. Namun, dalam ayat-ayat tersebut kata hari tetaplah harus dimengerti sebagai kelanjutan dari hari normal, dan selanjutnya kata hari juga dapat dimengerti sebagai bagian dalam satu tahun. Seperti penggunaan kata hari pada masa panen gandum atau "in the days of wheat harvest" dalam Kejadian 30:14 haruslah dimengerti sebagai beberapa minggu di dalam limitasi masa dari hari normal dalam tata surya, bukannya ribuan atau jutaan tahun. ${ }^{17}$

Dalam bahasa Indonesia terdapat perbedaan kata antara siang dengan hari, namun dalam bahasa Ibrani (yom) atau pun bahasa Inggris (day) menggunakan satu kata yang sama. Namun semenjak kemunculannya yang pertama, kata hari telah disandengkan dengan pengertian siang dan kemudian dipisahkannya dari gelap dan yang dinamai malam, dan oleh sebab itu pembacaan yang wajar akan bagian ini tentu saja dapat dilihat di dalam pengertian siang hari atau waktu hari kerja selama 12 jam. Hal ini juga sejalan dengan Yoh. 11:9, di mana Tuhan Yesus berkata, "bukankah ada dua belas jam dalam satu hari?" dan bila kita juga membandingkan kata hari baik dalam bahasa Ibrani, Yunani dan Inggris, kata hari memiliki beberapa arti primer dengan pengertian siang hari salah satunya. ${ }^{18}$

Hans M. Morris menyatakan bahwa ketika Allah menamakan terang itu hari/siang (yom) dan gelap itu malam, maka ini merupakan antisipasi bagi kesalahan penafsiran. Kata yom pertama kali digunakan untuk menamakan terang yang membedakannya dari malam. Dengan memisahkan siang dari malam maka Tuhan telah menyelesaikan hari penciptaan-Nya yang pertama, ditambah dengan formula "maka jadilah petang dan jadilah pagi" sebagai kesimpulan di dalam 6 hari tersebut. Sehingga, formula tersebut dengan sangat jelas menyatakan batasan dalam

17 Ibid., 108.

18 John C. Lennox, Tujuh Hari yang Membagi Dunia: Permulaan Dunia Menurut Kitab Kejadian dan Sains (Surabaya: Literatur Perkantas Jawa Timur, 2013), 53-54. Edisi tersebut dicetak dalam bahasa inggris dengan judul "Seven Days That Divide The World" pada tahun 2013. 
setiap harinya yang kemudian menjadi suatu rangkaian hari. Dan semua kriteria tersebut tidak pernah muncul dalam seluruh Perjanjian Lama diluar pengertian hari harfiah. Menurutnya, penulis kitab Kejadian menjaga dan melawan setiap kemungkinan bagi para pembacanya untuk menafsirkan hari penciptaan sebagai hari tidak harfiah. Dan karena itu, pengertian hari dalam perikop tersebut sudah menjadi sangat jelas, dimana durasi waktu dalam setiap hari adalah sama. ${ }^{19}$

Selanjutnya, bila kita amati secara terperinci maka kita akan menemukan bahwa mulai dari hari ke-1 hingga hari ke-5 ditulis dengan tidak menggunakan definite article sementara hari ke-6 dan ke-7 menggunakannya. Terdapat beberapa perdebatan memang terkait dengan tidak adanya definite article pada kata hari tersebut. Bruce Waltke percaya bahwa tidak adanya definite article pada 5 hari pertama menunjukkan kemungkinan urutan hari di dalam penciptaan tidaklah terjadi secara kronologis. Sementara, ia berasumsi bahwa adanya definite article pada hari ke-6 dan ke-7 menyatakan penekanan puncak klimaks dari narasi penciptaan tersebut pada dua hari yang penting tersebut. ${ }^{20}$ Namun, apabila melihat argumentasi dari frase "jadilah petang dan jadilah pagi" dalam skema hari kerja, maka kita akan menyadari bahwa ada dan tidaknya definite article berhubungan dengan selesai atau tidaknya hari penciptaan. Hadirnya kata hari di dalam setiap hari penciptaan merupakan suatu pengulangan dan sekaligus menjadi pembeda antara hari yang satu kepada hari yang berikutnya, sehingga menjadi penutup pada hari penciptaan yang bersangkutan. Dan oleh karena itu, penggunaan definite article pada hari ke-6 menjadi tanda bahwa pada hari tersebut penciptaan sudah selesai dan kemudian masuk kepada hari ke-7 di mana Tuhan juga tidak melakukan aktifitas penciptaan-Nya. Sehingga penggunakan artikel tersebut, untuk

19 Douglas F. Kelly, Creation and Change, 108-09.

20 Bruce K. Waltke and Charles Yu, An Old Testament Theology: An Exegetical, Canonical, and Thematic Approach (Grand Rapids: Zondervan, 2007), 62, 67. 
menyatakan berhentinya tindakan penciptaan pada hari tersebut. ${ }^{21}$

\section{Argumentasi Mengenai Hari Ke-7}

Bila kita meneliti lebih jauh mengenai hari ke-7, maka kita bisa menyadari dalam hari tersebut terdapat dua implikasi karya penciptaan Tuhan selama 6 hari. Implikasi tersebut adalah menjadikan hari tersebut harfiah dan juga pada saat bersamaan tidak harfiah. Dimana di dalam aspek harfiah, Tuhan berhenti bekerja pada hari yang spesifik tersebut, atau benarbenar berhenti secara harfiah di hari ke-7. Sedangkan aspek tidak harfiah dapat dimengerti di mana Tuhan berhenti untuk selama-lamanya di dalam karya penciptaan.

Memang penafsiran hari ke-7 sebagai hari yang bersifat tidak harfiah atau bahkan bersifat kekal telah dibahas begitu jelas di dalam Ibrani 4:1-13. Dan memang ketiadaan formula "Jadilah petang dan jadilah pagi" merupakan salah satu argumentasi yang melihat ke-tidak harfiah-an hari tersebut, karena menjadi penanda berhentinya karya penciptaan Allah pada hari ke-7 yang memiliki nilai kekal dan makna teologis. Sebagaimana Agustinus dalam penutupan dari pengakuannya menyatakan, "Hari ke tujuh tidak ada petang dan tidak ada kehadiran matahari, karena merupakan kelanjutan kekal di dalam pengudusan-Nya."22 Tentu saja hal tersebut merupakan kebenaran karena hari Sabat Tuhan tidaklah ada petang dan bahkan merupakan bagian di mana semua manusia akan masuk kedalamnya setelah akhir dari kehidupannya untuk selamanya. ${ }^{23}$ Lennox pun mengatakan bahwa pembaca kitab Kejadian jangan sampai terjebak dengan melihat aspek tidak harfiah hari ke-7 sehingga kemudian

21 Carl Friedrich Keil and Franz Delitzsch, Commentary On the Old Testament, 31.

22 Carl Friedrich Keil and Franz Delitzsch, 43. Pernyataan Agustinus di dalam bahasa aslinya: "dies septimus sine vespera est nec habet occasum, quia sanctificasti eum ad permansionem nem sempiternam."

23 Ibid., 43. 
mengaplikasikan pandangan tersebut ke dalam semua hari di dalam penciptaan menjadi tidak harfiah. Padahal penulis kitab Kejadian sudah dengan sangat jelas membedakan cara penulisannya, di mana dalam teks sendiri mengandung indikasi bahwa hari ketujuh berbeda dengan keenam hari yang lainnya. ${ }^{24}$

Perlu menjadi catatan bahwa unsur yang membuat hari ke-7 memiliki aspek tidak harfiah bukanlah terletak pada penggunaan kata hari itu sendiri, melainkan pada berhentinya aktifitas penciptaan Allah yang ditandai dengan ketiadaan frase "jadilah petang dan jadilah pagi" dan pada tindakan Allah yang menguduskan dan memberkati hari ke-7 tersebut. Penggunaan kata hari pada hari ke-7 justru memperkuat penafsiran harfiah hari-7. Pertama, dalam Kejadian 2:3 penulis merujuk hari ke-7 sebagai hari dimana Allah berhenti. Hal tersebut menuntut adanya hari ke-7 secara spesifik, karena bila tidak maka frase "pada hari itulah Ia berhenti..." tidak memiliki acuan pasti akan waktu dimana Allah berhenti dari segala pekerjaan-Nya. Kedua, Lennox juga mengungkapkan bahwa setiap bagian yang menyebutkan dasar mengenai hari Sabat teokratis, mengindikasikan mengenai hari biasa seperti yang dinyatakan di dalam Keluaran 20:11 dan 31:17. 25 Selain itu 6 hari penciptaan tersebut adalah 6 hari biasa sebagaimana yang telah dinyatakan di dalam teks Kejadian 1, dan oleh sebab itu kita harus pula dapat melihat terdapatnya aspek harfiah di dalam hari ke-7.26

Di sisi lain, Bill T. Arnold melihat bahwa siklus 7 hari dalam satu minggu bukanlah sesuatu yang normal, melainkan hasil konstruksi karena bukan seperti tahun atau bulan atau pun hari yang didasarkan dari fenomena kosmis yang dapat diamati berdasarkan pergerakan dari bintang dan planet-planet. Sehingga skema 7 hari dalam satu minggu yang berakhir

\footnotetext{
24 John C. Lennox, 54-55.

25 Ibid., 43.

26 Ibid., 43.
} 
dalam hari Sabat yang kudus merupakan keunikan bangsa Israel dibandingkan dengan filosofi bangsa-bangsa Timur Dekat Kuno yang lainnya. ${ }^{27}$

Lebih lanjut E. J. Young menyatakan bahwa natur dari kitab Kejadian merupakan semata-mata pewahyuan khusus dari Allah akan penciptaan langit, bumi dan manusia, dan bukanlah seperti sejarah manusia pada umumnya. ${ }^{28}$ Oleh karena itu, kita dapat mengatakan dengan gamblang bahwa kisah penciptaan di dalam 6 hari plus 1 hari merupakan wahyu khusus dari Allah, dan juga pengertian mengenai 7 hari dalam 1 minggu merupakan wahyu khusus Allah kepada Musa. Dengan demikian jelaslah bahwa pola 7 hari dalam Kejadian 1:1-2:3 mengubah minggu, dengan waktu reguler 24 jam dalam satu harinya, menjadi suatu peringatan tetap akan karya penciptaan Allah yang berdaulat. Sehingga setiap minggu dalam sejarah kehidupan manusia menjadi pengingat dalam dunia ciptaan sepanjang jaman. ${ }^{29}$

\section{Argumentasi Penciptaan Secara Kronologis}

Meskipun penerimaan penafsiran kata hari secara harfiah mengasumsikan penerimaan akan penciptaan secara kronologis, namun argumentasi penciptaan kronologis juga merupakan pembahasan yang sangat penting untuk mendukung penafsiran hari harfiah. Pandangan tersebut melihat bahwa hari penciptaan bukan hanya dimengerti secara 6 hari harfiah tetapi bahkan urutan di dalam hari penciptaan pun dilihat

27 Bill T. Arnold, Genesis, New Cambridge Bible Commentary (Cambridge: Cambridge University Press, 2009), 49. Terdapat para ahli yang menyatakan bahwa perayaan 7 hari dalam budaya Israel merupakan apologetika dan polemik yang diciptakan untuk melawan konsep budaya Mesopatamia. Di sisi lain skema 7 hari menjadi motif umum di dalam sastra dalam jaman Ugaritic, yang sedang ingin menyatakan "ekspresi proses yang panjang", khususnya ditemukan di dalam pembangunan kuil bagi Baal yang mengambil waktu selama 7 hari.

28 Edward J. Young and Robert Young, Studies in Genesis One (Phillipsburg: P \& R, 1999), 75.

29 Bill T. Arnold., 49-50. 
terjadi secara berurutan dan kronologis.

Diawali dengan pengertian akan yom ehad atau hari satu, dengan melihat contoh lain di dalam Kejadian 2:11; 4:19; 8:5 yang menyatakan suatu pembukaan dari urutan angka yang mengikutinya. ${ }^{30}$ Sehingga menandakan adanya urutan kronologis yang sangat jelas. Di lain sisi, penggunaan kata "satu" tersebut di dalam kerangka hari penciptaan dapat dipahami sebagai belum diciptakannya hari yang lain, sehingga membuat hari tersebut menjadi satu-satunya hari yang ada. ${ }^{31}$ Dimana mempersiapkan pernyataan hari penciptaan berikutnya yang didasarkan atau dibangun berdasarkan karya penciptaan pada hari sebelumnya, sebagaimana benda penerang yang diciptakan pada hari ke-4 diletakkan pada langit yang telah diciptakan pada hari ke-2, dan ikan-ikan yang diciptakan pada hari ke-5 diletakkan pada laut yang telah ada sebelumnya di hari ke-3, dan demikian seterusnya. ${ }^{32}$

Selain itu, sangat menarik bahwa Collins yang memegang pandangan Analogical Day-Theory tetap meyakini bahwa penciptaan haruslah di dalam urutan kronologisnya. Collins menyatakan bahwa penggunaan dari wayyiqtol (waw-consecutive with imperfect) menyatakan suatu teknik penulisan yang umum digunakan dalam narasi, yang berfungsi menandakan pemisahan dan secara mendasar menyatakan suatu peristiwa yang berurutan bersama dengan penggunaan angka yang semakin memuncak. Hal tersebut menurutnya merupakan sesuatu yang berarti di dalam penulis memaparkan peristiwa yang terjadi. ${ }^{33}$ Lebih lanjut, ia juga menyatakan bahwa peristiwa yang terjadi dalam narasi penciptaan tersebut sebagai suatu peristiwa yang benar-benar terjadi di dalam sejarah sebagaimana

30 Carl Friedrich Keil and Franz Delitzsch, Commentary On the Old Testament,31.

31 Frank E. Gaebelein, Expositor's Bible Commentary, vol. 2, Genesis - Numbers (Grand Rapids: Zondervan, 1990), 28.

32 Vern S. Poythress, Christian Interpretations of Genesis 1, Christian Answers to Hard Questions (Philadelphia: Westminster Seminary Press, 2013), 22-23.

33 C. John Collins, Genesis 1-4: A Linguistic, Literary, and Theological Commentary (Phillipsburg: P $\& \mathrm{R}, 2006), 21,74$. 
penulis kitab Kejadian membangun argumentasinya di dalam seluruh pasal berdasarkan 3 pasal pertama di dalam kitab Kejadian. Di mana pertamatama, kitab Kejadian menyatakan suatu koneksi antara sepasang manusia pertama dengan keturunan yang masuk ke Mesir, dan kitab Kejadian juga menjadi bagian dari keseluruhan narasi di dalam lima kitab Musa yang sangat tertarik dengan peristiwa sejarah. ${ }^{34}$

\section{Argumentasi Mature Creation Theory}

Pandangan tersebut menjadi salah satu argumentasi yang mencoba memperkuat penafsiran harfiah mengenai hari penciptaan. Hal ini disebabkan karena pandangan tersebut menerima semua argumentasi yang diberikan young earth creationism atau 24 hour-day theory tetapi tetap berusaha untuk menjawab tantangan kontemporer dari ilmu pengetahuan yang menyatakan bahwa bumi berusia sudah sangat tua. Dengan penjelasan yang singkat dan jelas pandangan tersebut mencoba memberikan suatu kesimpulan terhadap teori astronomi modern, dengan mengatakan bahwa alam semesta ini terlihat berusia 14 miliyar tahun karena pada waktu Tuhan menciptakannya sudah di dalam keadaan yang dewasa. Sama seperti halnya ketika Tuhan menciptakan Adam, sudahlah tentu Adam diciptakan di dalam keadaannya yang sudah dewasa. Selanjutnya, alam semesta ini terlihat sudah berusia sangat tua karena adanya perbedaan metode penelitian dalam mengukur usia alam semesta, sehingga hasilnya pun tidak akan dapat menemukan usia yang sebenarnya. ${ }^{35}$

Withcomb menganggap bahwa hal yang bersifat supernatural dan kesegeraan merupakan konsep penting dalam penciptaan. Sehingga ciptaan tersebut tidak mungkin tidak memiliki usia yang terlihat ketika diciptakan. Salah satu mujizat yang tercatat mengenai hal ini adalah peristiwa Tuhan

$34 \quad$ Ibid., 251.

35 Vern Poythress, Redeeming Science: A God-Centered Approach. (Wheaton: Crossway, 2006), 116. 
Yesus memberi makan 5000 orang di dekat danau Galilea. Di mana 5000 laki-laki dan keluarganya menikmati makanan berupa roti dan ikan di dalam usia yang terlihat telah mature atau memiliki appearance of age. Roti tersebut tidaklah dibuat dengan serentetan peristiwa yang harusnya ada, yakni menanam, memanennya, dan kemudian mengolah gandum menjadi roti. Demikian pula halnya dengan ribuan ikan yang dinikmati orang-orang tersebut tidaklah pernah ditelurkan, ditangkap, dikeringkan di bawah matahari dan kemudian baru diolah. ${ }^{36}$ Dengan sangat brilian Lubenow menyatakan kedua peristiwa Tuhan Yesus memberi makan kepada 4000 dan kepada 5000 orang melibatkan peristiwa penciptaan yang bersifat instan baik binatang maupun tumbuhan, yang memberikan kita pengertian akan penciptaan binatang dan tumbuhan di dalam hari ketiga, kelima dan keenam dalam Kejadian $1 .^{37}$

Begitu pula dengan peristiwa air menjadi anggur merupakan peristiwa yang memuliakan Kristus (Yoh. 2:11), di mana bila kita coba untuk cermati anggur yang baik terjadi dari serangkaian peristiwa, mulai dari proses pemanenan hingga proses didiamkan bertahun-tahun agar menjadi anggur berkualitas. Apa yang dikerjakan Tuhan Yesus di sini bukan hanya melewati semua proses tersebut, tetapi juga mengubah susunan kimiawi dari air $\mathrm{H}_{2} \mathrm{O}$ menjadi $\mathrm{C}_{6} \mathrm{H}_{12} \mathrm{O}_{6}$. Peristiwa ini bukan hanya merupakan proses penciptaan jutaan atom karbon tetapi juga termasuk proses perangkaian atom-atom tersebut menjadi susunan molekul kompleks di dalam anggur. ${ }^{38}$

\section{Argumentasi Flood Geology Theory}

Peristiwa air bah adalah suatu peristiwa sangat besar, yang menjadi suatu pembeda jaman. Meskipun demikian peristiwa tersebut dianggap

\footnotetext{
36 John Clement Whitcomb, The Early Earth, rev. ed. (Grand Rapids: Baker, 1986), 40-41.

37 Marvin L. Lubenow, "From Fish to Gish": Morris and Gish Confront the Evolutinary Establishment (San Diego: CLP, 1983), 196.

38 Ibid., 196.
} 
hanya sebagai dongeng dan ditafsirkan sebagai suatu peristiwa lokal. Hal ini disebabkan oleh banyaknya narasi-narasi di dalam Timur Dekat Kuno yang menceritakan hal serupa seperti cerita Gilgamesh. C.W Ceram menganalisa bahwa penemuan-penemuan arkeologi tersebut menyatakan dengan sangat jelas bahwa kisah Alkitab tentang air bah bersumber dari Babilonia. Dan karenanya, Alkitab tidak dapat dilihat hanya sebagai pewahyuan murni tetapi haruslah dilihat di dalam rajutan mitos yang bersumber dari warisan budaya kuno. ${ }^{39}$

Namun, analisa tersebut tidaklah tepat karena kedua narasi tersebut berangkat dari peristiwa yang benar-benar terjadi, dan kemudian keturunan Nuh menyebar ke seluruh belahan bumi dan semakin menjauh dari Tuhan, yang menyebabkan mereka menjadi semakin rusak di dalam budaya polytheisme. Dan apabila kita teliti dengan seksama, cerita Gilgamesh tersebut didasarkan dari kisah sebelumnya yakni cerita Sumeria yang mana Ziusudra adalah nama dari pembuat bahtera, dan kemudian di ceritakan ulang di dalam narasi Gilgamesh dengan adanya perubahan. Sehingga hal tersebut terus bergulir dan semakin jauh dari peristiwa yang sebenarnya yang dinyatakan di dalam Alkitab.40

Selain itu, kita dapat melihat kesaksian peristiwa tersebut di dalam seluruh Alkitab mulai dari Kejadian 6:17; 7:4,19-20,23; 9:11; Mazmur 29:1-11; 104:5-9; Yesaya 54:9; Matius 24:37-39; Lukas 17:26-27; Ibrani 11:7; 1 Petrus 3:19-20; 2 Petrus 2:5; 3:3-6, dan semua bagian tersebut menyatakan bahwa air bah terjadi secara universal. Ditambah lagi bila kita mengamati pegunungan Ararat yang memiliki ketinggian 17 ribu kaki ditenggelamkan oleh air bah tersebut dan barulah sekitar 2,5 bulan setelah bahtera mendarat puncakpuncak gunung dapat terlihat, belum lagi ditambah 4,5 bulan menunggu air untuk surut sebelum mereka dapat meninggalkan bahtera. Sehingga

39 Alfred J. Hoerth, Archaeology and the Old Testament (Grand Rapids: Baker, 2009), 196.

40 Ibid.,196. 
membayangkan air bah yang terjadi selama satu tahun, dengan gunung yang tingginya 17 ribu kaki sebagai peristiwa lokal adalah sangat tidak masuk akal. ${ }^{41}$ Dalam keyakinan akan peristiwa tersebut benar-benar terjadi secara historis, maka kita dapat memahami terjadinya bencana alam yang sangat besar terjadi di seluruh dunia. Dimana peristiwa yang membuat gunung-gunung terbenam pastilah secara fisik akan sangat memengaruhi struktur geografis dan stratigraphic dari permukaan Bumi, sehingga membuat hampir mustahil untuk dapat menentukan secara pendekatan geologi apa yang terjadi sebelum air Bah. Bencana alam dengan skala sangat besar dan terjadi secara serentak diikuti dengan aktivitas vulkanik dan tektonik pada skala besar menjelaskan dengan sangat baik keadaan geologi pada saat ini. ${ }^{42}$ Hal inilah yang kemudian menjelaskan bagaimana fosil, minyak bumi, dan gas alam yang dianalisa berusia jutaan tahun dapat terjadi dalam waktu singkat. Untuk memperkuat argumentasi ini, telah terdapat suatu fakta yang menarik, yaitu minyak dan gas bumi yang dianalisa terbentuk jutaan tahun dapat dibuat di dalam waktu sekitar 20 menit dibawah suhu dan tekanan yang tepat. Bahkan kayu dan tanamantanaman yang lain juga dapat dikonversi menjadi batubara dan bahan bakar sejenisnya hanya di dalam beberapa jam. Sehingga penelitian tersebut membuktikan bahwa terbentuknya batubara, minyak dan gas tidaklah harus membutuhkan waktu jutaan tahun seperti pandangan dari kebanyakan ahli geologi. ${ }^{43}$ Bahkan terdapat suatu fakta penemuan yang mengejutkan, yakni diketemukannya pada tahun 1968 di Utah fosil dari beberapa trilobite, dan sebuah jejak kaki bersandal dari seorang manusia. Sehingga hal tersebut menjadi anomali di dalam standar pembagian usia lapisan geologi, di mana seharusnya trilobite punah semenjak 230 juta tahun lalu sebelum munculnya

\footnotetext{
41 Henry M. Morris, Science and the Bible, rev. and updated. ed. (Chicago: Moody, 1986), 64-65.

42 Ibid., 65-66, 82.

43 Ibid., 40.
} 
manusia. ${ }^{44}$ Selain itu, juga ditemukannya tulang manusia dan beberapa benda-benda seperti rantai emas di dalam sumber batu bara yang dianggap telah terbentuk selama jutaan tahun sebelum manusia berevolusi.

\section{Perdebatan Terkait Penafsiran Hari Secara Harfiah}

Selain dari argumentasi diatas, terdapat pula beberapa hal yang menjadi perdebatan sebagai implikasi dari pengertian hari yang kronologis dan harfiah. Dengan salah satu tantangan yang terbesar adalah dari kelompok yang melihat narasi tersebut hanya sebagai mitos atau legenda sebagaimana yang dikatakan oleh James Barr,45 ataupun yang menganggap di dalam narasi penciptaan terdapat penggunaan anthropomorphic. Sementara di sisi lain, pandangan tidak harfiah mempertanyakan posisi Kejadian 1 dengan Kejadian 2 di dalam urutan kronologisnya yang terlihat berbeda. Sehingga kita akan mencoba mengangkat beberapa argumentasi lain yang mencoba memperkuat pandangan penafsiran secara harfiah tersebut. Dan terakhir kita akan melihat sudut pandang yang berbeda untuk mengimbangi pendekatan ilmu pengetahuan yang mengatakan terjadinya alam semesta dan bumi memakan waktu yang sangat lama.

\section{Argumentasi Tantangan Kronologis Kejadian 2 terhadap Kejadian 1}

Urutan kronologis narasi penciptaan di dalam Kejadian 1 mendapatkan tantangan dari narasi yang terdapat di dalam Kejadian 2 karena urutan kronologis penciptaannya terlihat berbeda dari urutan yang dinyatakan di dalam Kejadian 1. Sehingga, terdapat pandangan yang meragukan bahwa urutan di dalam penciptaan di dalam Kejadian 1 dinyatakan secara kronologis. Di sisi lain, mereka kerap melihat bahwa

$44 \quad$ Ibid., 34.

45 Hamilton, Genesis, 54. 
standar pencatatan sejarah di dalam Alkitab berbeda dengan standar pencatatan saat ini. Dan ketika melihat narasi penciptaan yang notabene belum ada manusia pada saat itu, dengan begitu gampangnya kemudian menilai para penulis Alkitab hanya mengumpulkan data-data dan kemudian menyusunnya. Sehingga tentu saja akan menyimpang dari urutan kronologis. ${ }^{46}$

Namun bila dengan teliti kita melihat kedua perbedaan narasi penciptaan tersebut, maka kita akan menemukan bahwa Kejadian 2 merupakan suatu pendahuluan kepada narasi kejatuhan umat manusia dalam pasal 3. Dan melalui analisa mendalam kita dapat melihat bahwa penulisan Kejadian 2 justru menjadi salah satu contoh di dalam Alkitab yang tidak menggunakan pertimbangan penulisan kronologis. ${ }^{47} \mathrm{Kita}$ dapat melihat struktur di dalam bagian ini yang dengan sederhana memperlihatkan bahwa urutan kronologis memang sedang tidak diintensikan. ${ }^{48}$ Berikut struktur dari Kejadian 2 yang dapat kita amati di bawah ini: 49

2. 4-25 (J', above). MAN BEFORE THE FALL.

(Introversion and Extended Alternation.)

J'A | 2. 4, 5-. The earth for man and woman.

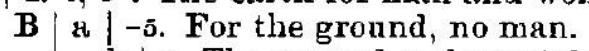

b | 6 . The ground.and vegetable creation.

c| 7. The formation of man.

C $\mid$\begin{tabular}{l|l} 
d & 8. The Garden. \\
& is. The Trees.
\end{tabular}

D | 10-14. The Rivers.

c $d \mid$ 15. The Garden. e| 16, 17. The Trees.

$B ; a \mid$ 18. For the man, no woman.

b| $19,20-$. The ground and animate creation.

c) $-20 \cdot \cdot 23$. The formation of woman.

A $\mid 24,25$. Man and woman for the earth.

\footnotetext{
46 Young, Genesis, 73.

47 Ibid.,74.

48 Ibid., 74.

49 E. W. Bullinger, Companion Bible: King James Version, Burgundy, Bonded Leather, Burgundy Bonded Leather ed. (Grand Rapids: Kregel, 1990), 5.
} 
Melalui struktur tersebut kita bisa mengamati bahwa Tuhan membentuk manusia terlebih dahulu (Kej. 2:7), kemudian baru membuat taman (Kej. 2:8a), setelah itu barulah menempatkan manusia di dalamnya (Kej. 2:8b), lalu setelah manusia berada dalam taman tersebut Tuhan barulah menumbuhkan berbagai-bagai macam pohon (Kej. 2:8b), dan kemudian barulah kembali memaparkan mengenai sungai yang mengalir di taman Eden (Kej. 2:10-14), dan setelah semua ini Tuhan kembali menempatkan manusia ke dalam taman Eden tersebut (Kej. 2:15a). Apabila kita mengamati struktur tersebut secara kronologis maka akan begitu banyak pertanyaan yang muncul, seperti: Berapa kalikah Tuhan menempatkan manusia ke dalam taman? Apa yang Tuhan lakukan kepada manusia sebelum Ia menempatkannya ke dalam taman? Berapa kalikah Tuhan menanam dalam taman tersebut, atau Tuhan pertama kali menanam tanaman dan kemudian baru pohon? Sehingga melalui skema tersebut, jelaslah Musa memiliki tujuan selain mau menunjukkan urutan kronologis. 50

Oleh karena itu, pembacaan dalam bagian tersebut memang bukanlah secara kronologis melainkan kita harus melihat bagian tersebut di dalam relasinya kepada Kejadian pasal 3, yang menekankan kepada kejatuhan manusia. Dan oleh sebab itu, dengan jelas kita dapat katakan bahwa Kejadian 2 bukanlah narasi penciptaan kedua dan penafsiran di dalam bagian ini janganlah mencoba untuk mengharmonisasikan narasi penciptaan di dalam Kejadian 1 dan 2.51 Dengan demikian kita justru dapat melihat bahwa Kejadian 2 sangat menekankan mengenai manusia, di mana taman Eden diciptakan oleh karena manusia sebagai "tamu" Tuhan di dalam dunia, dan kemudian taman tersebut didandani dengan begitu indah, dan manusia ditempatkan di dalamnya. Sehingga manusia ditempatkan sebagai hamba Tuhan untuk bekerja dalam taman yang adalah milik Allah

50 Young, Genesis, 74.

51 Ibid., 74. 
sendiri dengan batasan untuk tidak memakan buah pengetahuan baik dan jahat. 52

Dan puncak klimaks dari narasi Kejadian 2 tersebut terdapat di dalam ayat 25, di mana disebutkan "mereka keduanya telanjang, manusia dan istrinya itu, tetapi mereka tidak merasa malu". Dalam seluruh PL, kata telanjang dimengerti sebagai referensi dari kelahiran, penggambaran orang miskin, dan sebagai tanda bersalah atau rasa malu. Dimana telanjang sebagai simbol bersalah adalah penggunaan yang paling sering. ${ }^{53}$ Sehingga penggunaan frase tersebut dengan jelas menyatakan koneksi sangat kuat antara ketelanjangan dan rasa malu, yang terjadi setelah kejatuhan manusia kedalam dosa dalam Kejadian 3. Di mana sebelum jatuh mereka memang telanjang tetapi mereka tidak malu, sebab mereka baik dan tidak ada kejahatan di dalam mereka. ${ }^{54}$

Sebagai kesimpulan hari penciptaan di dalam Kejadian 1 haruslah dipahami di dalam konteks pada pasal tersebut, khususnya di dalam kaitan urutan kronologis hari penciptaan. Sementara fakta bahwa Kejadian 2 dipaparkan di dalam urutan non-kronologis tidaklah menjadi dasar bagaimana Kejadian 1 harus ditafsirkan. 55

\section{Argumentasi Terhadap Mitos}

Kitab Kejadian 1-11 seringkali digambarkan sebagai mitos oleh karena kisah tersebut merefleksikan kisah prescientific dan juga nonscientific worldview. Sehingga semua hal yang berkaitan dengan karya dari Allah atau sesuatu yang Ilahi, yang mana oleh pendekatan scientific worldview diintepretasikan sebagai kaidah hukum alam yang impersonal, adalah mitos. Dan mitos juga bukan hanya merupakan pernyataan figuratif dari

\footnotetext{
52 Ibid., 74-75.

53 Hamilton, Genesis, 181.

54 Young, Genesis, 75.

55 Ibid., 76.
} 
kebenaran tetapi ekspresi atau pernyataan yang salah dari kebenaran. Sehingga semua cerita tentang Tuhan atau semua jenis cerita supernatural adalah mitos. ${ }^{56}$ Sehingga melalui definisi tersebut kita mengetahui bahwa definisi dari Mitos berkembang bukanlah dari pembelajaran mengenai subjek Mitologi, melainkan dari perlawanan antara mitos dengan science. ${ }^{57}$ Bruce Waltke menambahkan mitos adalah sesuatu yang membahas mengenai karya metafisik dan tidak dapat diketahui oleh pendekatan ilmu pengetahuan..$^{58}$ Oleh sebab itulah, Rudolf Bultmann berasumsi bahwa orang modern untuk dapat mengetahui Alkitab perlu melakukan pendekatan demitologisasi. ${ }^{59}$

Akan tetapi, argumentasi yang sedang ingin menyatakan kitab Kejadian sebagai mitos sungguhlah sangat sedikit, karena semua elemen kunci dari mitos tidaklah ada di dalam perikop tersebut. Seperti tidak ada allah-allah, tidak ada penciptaan yang bersifat berkelanjutan/berulang-ulang, tidak ada konflik antara kebaikan dan kejahatan atau konflik antara keteraturan dan kekacauan (sebagaimana yang telah kita bahas sebelumnya), tidak ada pembahasan tentang seksualitas dalam narasi penciptaan sebagaimana terdapat di seluruh narasi penciptaan yang lain, dan memandang tinggi kemanusiaan. Sehingga kalau pun narasi penciptaan dalam Kejadian 1 ditulis di dalam bahasa mitos, maka narasi penciptaan tersebut benar-benar telah ditulis ulang untuk melenyapkan bentuk penulisan-penulisan mitos yang sebelumnya di dalam narasi penciptaan Timur Dekat Kuno. ${ }^{60}$

Sebagaimana yang telah sedikit disinggung dalam eksegesis Kejadian 1:2, sering tudingan tersebut muncul karena terkesan ayat tersebut

\footnotetext{
56 Hamilton, Genesis, 56-57.

57 Ibid., 57.

58 Waltke, Old Testament Theology,74.

59 Hamilton, Genesis, 57.

60 John N. Oswalt, The Bible Among the Myths: Unique Revelation or Just Ancient Literature? (Grand Rapids: Zondervan, 2009), 99.
} 
menyatakan adanya preexistence chaos yang serupa dengan narasi Enuma Elish. Dan setelah kita kaji ternyata Kejadian 1:2 tidaklah melihatnya demikian. Selanjutnya argumentasi yang lain pun muncul untuk berusaha mempersama-samakan narasi penciptaan dalam Kejadian dengan Enuma Elish seperti apa yang dilakukan oleh Alexander Heidel berikut: ${ }^{1}$

\begin{tabular}{|l|l|}
\hline \multicolumn{1}{|c|}{ Enuma Elish } & \multicolumn{1}{|c|}{ Genesis } \\
\hline $\begin{array}{l}\text { Divine spirit and cosmic } \\
\text { matter are coexistent and } \\
\text { coeteral }\end{array}$ & $\begin{array}{l}\text { Divine Spirit create cosmic } \\
\text { matter and exists independently } \\
\text { of it }\end{array}$ \\
\hline $\begin{array}{l}\text { Primeval Chaos; Tiamat } \\
\text { enveloped in darkness }\end{array}$ & $\begin{array}{l}\text { Earth a desolate waste, with } \\
\text { darkness covering the deep }\end{array}$ \\
\hline Light emanating from the gods & Light created \\
\hline The creation of the firmanent & The creation of the firmament \\
\hline The creation of the dry land & The creation of the dry land \\
\hline The creation of the luminaries & The creation of the luminaries \\
\hline The creation of man & The creation of man \\
\hline The Gods rest and celebrate & $\begin{array}{l}\text { God rests and sanctifies the } \\
\text { seventh day }\end{array}$ \\
\hline
\end{tabular}

Meskipun bila dilihat sekilas mirip, namun hal yang esensial berbeda adalah terdapatnya perbedaan kesimpulan. Enuma Elish dalam narasi pembukaannya menyatakan kemunculan para allah dari chaos, dan kemudian menceritakan bagaimana para allah tersebut saling kawin dan beranak cucu, adanya persekongkolan antara Tiamat dan Apsu untuk membunuh para dewa yang pada akhirnya menimbulkan peperangan. Belum lagi hadirnya Marduk sebagai dewa yang mengalahkan Tiamat dengan membelah tubuhnya jadi dua yang dipakai untuk membuat langit,

61 Alexander Heidel, The Babylonian Genesis: The Story of Creation, 2nd ed. (Chicago: University of Chicago Press, 1963), 129. 
memisahkan air yang ada di atas dan yang ada dibawah. Diperkeruh dengan penciptaan manusia menggunakan tanah dan darah Tiamat untuk dijadikan budak para dewa. ${ }^{62}$ Setelah melihat semua ini, maka narasi penciptaan Enuma Elish adalah asing dalam narasi penciptaan dalam kitab Kejadian. Dan kisah Enuma Elish sama-sekali bukanlah tentang penciptaan, karena penciptaan di mengerti di dalam kitab Kejadian adalah menjadikan sesuatu yang belum ada sebelumnya (creatio ex nihilo). Sehingga semua narasi penciptaan di Mesopotamia dan bersama dengan narasi penciptaan Timur Dekat Kuno, terlepas dari narasi penciptaan dalam Kejadian. ${ }^{63}$ Selain itu, Hoerth seorang ahli dalam bidang arkeologi menyatakan dengan sangat tegas, bahwa persamaan yang ada antara narasi penciptaan dalam kitab Kejadian dengan Enuma Elish, seperti penciptaan cakrawala, tanah, bintangbintang, manusia dan bahkan diakhiri oleh istirahat Ilahi, sama sekali tidak bermakna karena persamaan tersebut dengan sangat mudah dijelaskan dengan kebetulan yang pasti muncul di dalam dua karya yang berbicara tema yang sama dan tidaklah mungkin tidak ada tumpang tindih cerita di dalamnya. ${ }^{64}$

Dan bila mengamati lebih jauh narasi Enuma Elish maka narasi tersebut memiliki tujuan meninggikan Marduk dan menyatakan kemenangan berkelanjutan atas keteraturan diatas kekacauan. Sementara kitab Kejadian tidak memiliki tujuan tersebut, dimana karya penciptaan merupakan gambaran dari kehendak Allah, dan terdapat perbedaan antara creator and creation. Natur dari mitos di dalam Timur Dekat Kuno sendiri tidak dapat membedakan para allah dengan materi, karena mereka memiliki konsep bahwa para allah keluar dari materi, sehingga allah dan materi memiliki relasi secara ontologi dan bukan secara figuratif. Di mana konsep

\footnotetext{
62 Victor Harold Matthews and Don C. Benjamin, Old Testament Parallels: Laws and Stories from the Ancient Near East, 3rd ed. (New York: Paulist, 2006), 13-20.

63 Oswalt, The Bible Among the Myths, 100-101.

64 Hoerth, Archaeology and the Old Testament, 185-187.
} 
tersebut sangatlah asing di dalam Alkitab. 65

Selain itu, penelitian Oswalt mengungkapkan tidak adanya fitur esensial dari mitos di dalam kitab Kejadian, seperti: Politeisme, gambar dalam bentuk materi, kekacauan kekal, pribadi yang tidak esensial pada realita, pandangan yang rendah akan para Dewa, konflik sebagai sumber kehidupan, pandangan yang rendah atas kemanusiaan, tidak ada satu standar etika dan konsep keberadaan secara siklus. Oleh karena itu, pengaruh langsung dari kisah penciptaan Babilonia kepada narasi penciptaan di dalam Alkitab tidaklah terdeteksi. ${ }^{66}$ Dan bukan hanya itu saja, Alfred berargumentasi bahwa penemuan arkeologi yang ada justru menyatakan dengan sangat jelas bahwa kitab Kejadian tidak bergantung dan tidak berhutang apa pun terhadap semua budaya kuno dan mitos-mitos mereka. Dimana Allah dalam kitab Kejadian bukanlah allah yang menakutkan, bermusuhan dan bodoh seperti dalam mitos-mitos tersebut. Dengan menyadari hal tersebut kita justru perlu bersyukur bahwa bangsa Israel ditarik keluar oleh Tuhan dari cerita-cerita membingungkan kepada cerita yang sungguh-sungguh terjadi melalui perantaraan Musa. ${ }^{67}$

Dan melalui pembahasan struktur kitab Kejadian, kaitan antara seluruh perikop "silsilah," mulai silsilah langit dan bumi hingga kepada silsilah Yakub dalam Kejadian 37:2 sedang menyatakan 10 rangkaian sejarah silsilah yang tidak terputus dari penciptaan langit dan bumi hingga kepada bangsa Israel. Sebagaimana yang terlihat pada outline berikut ini: ${ }^{68}$

$\begin{array}{lll}\text { 2:4a } & \text { tôlĕdôt dari Langit dan Bumi } & 2: 4 b-4: 26 \\ \text { 5:1a } & \text { tôlĕdôt dari Adam } & 5: 1-6: 8 \\ \text { 6:9a } & \text { tôlĕdôt dari Nuh } & 6: 9-9: 29\end{array}$

65 Hamilton, Genesis, 59.

66 Oswalt, The Bible Among the Myths, 57-62, 101-03.

67 Hoerth, Archaeology and the Old Testament, 187.

68 Bill T. Arnold, Genesis, New Cambridge Bible Commentary (Cambridge: Cambridge University Press, 2009), 6. 


$\begin{array}{lll}\text { 10:1a } & \text { tôlĕdôt dari Keturunan Nuh } & 10: 1-11: 9 \\ \text { 11:10a } & \text { tôlĕdôt dari Sem } & 11: 10-26 \\ \text { 11:27a } & \text { tôlĕdôt dari Terah } & 11: 27-25: 11 \\ \text { 25:12a } & \text { tôlĕdôt dari Ismael } & 25: 12-18 \\ \text { 25:19a } & \text { tôlĕdôt dari Ishak } & 25: 19-35: 29 \\ 36: 1 a & \text { tôlĕdôt dari Esau } & 36: 1-37: 1 \\ 37: 2 a & \text { tôlĕdôt dari Yakub } & 37: 2-50: 26\end{array}$

Oleh karena itu, dengan melihat keterkaitan yang sangat erat di dalam kitab Kejadian tersebut, maka haruslah disimpulkan bahwa narasi penciptaan adalah narasi sejarah dan bukanlah mitos, terlebih lagi merupakan suatu kejadian yang benar-benar terjadi secara harfiah. Akan tetapi, ketika narasi silsilah langit dan bumi dikategorikan sebagai mitos maka konsekuensinya seluruh narasi sejarah yang terdapat di dalam kitab Kejadian jugalah harus dikategorikan sebagai mitos, yang tentu saja akan berkulminasi bahwa kematian Tuhan Yesus Kristus di atas kayu salib yang menyelamatkan dan menebus umat pilihan pun adalah mitos karena hal tersebut tidaklah dapat dibuktikan di dalam pendekatan ilmu pengetahuan. Sebagaimana Peter Enns dengan gamblang di dalam skema evolusi melihat adanya kemungkinan bahwa Adam dan Hawa adalah dua golongan primata atau hominid yang di dalam satu titik perkembangan evolusi terdapat intervensi Tuhan menjalin relasi dengan mereka dengan memberikan gambar-Nya dan dengan demikian membuat "primata" tersebut menjadi manusia yang menyadari keberadaan dirinya. ${ }^{69}$ Oleh sebab itu, pandangan Paulus yang melihat Adam sebagai nenek moyang dari umat manusia tidak mungkin dapat masuk di dalam skema evolusi. Sehingga dalam pengertian ini Enns menyatakan kita tidak dapat mencampur dua cerita penciptaan baik mengharmonisasikan science kepada pengertian Alkitab maupun

69 Peter Enns, The Evolution of Adam: What the Bible Does and Doesn't Say About Human Origins (Grand Rapids: Brazos Press, 2012), 138. 
sebaliknya. ${ }^{70}$

Memang tidak semua pandangan tidak harfiah akan berakhir dengan meragukan historisitas Adam sebagai manusia pertama. Namun, sekali lagi implikasi dari pandangan tersebut membuka kemungkinan yang besar bagi teori evolusi yang kemudian membuka kemungkinan bagi non-historikal Adam dan tentu saja dengan demikian seluruh konsep di dalam Alkitab terbuka untuk diragukan.

Di sisi lain, James Barr menilai penafsiran hari dalam Kejadian 1 haruslah dimengerti sebagai hari yang harfiah. Hal ini didasarkan dari isu penafsiran (hermeneutic) yang seharusnya mencoba memahami pengertian hari dari sang penulis dan bukannya pengertian hari dalam benak para penafsir jaman ini. Akan tetapi fakta-fakta ilmu pengetahuan saat ini menyatakan adalah suatu kebodohan untuk berpikir bahwa alam semesta diciptakan dalam 1 minggu. ${ }^{71}$ Sehingga pada akhirnya James Barr mendapatkan konklusi bahwa memang narasi penciptaan di dalam kitab Kejadian dipahami baik oleh penulis maupun pendengar secara harfiah namun oleh karena berbeda dengan fakta-fakta ilmu pengetahuan maka Kejadian 1 harus ditafsirkan sebagai mitos atau legenda. Kemudian ia melihat inilah sebabnya mengapa banyak komentator konservatif menghindari penafsiran harfiah dari Kejadian 1 dan mengganti penafsirannya dengan penafsiran yang figuratif. ${ }^{72}$

\section{Argumentasi Terhadap Bahasa Anthropomorphic}

Di dalam tantangan ilmu pengetahuan dengan narasi penciptaan di dalam Kejadian 1 dan 2, para ahli kemudian mencoba untuk memikirkan kembali metodologi penafisran narasi penciptaan tersebut. Salah satu

\footnotetext{
Ibid., 139.

Ibid., 54 .

Ibid., 54.
} 
metode yang terlihat logis adalah di dalam pendekatan gaya bahasa Anthropomorphic. Di mana ketika narator menceritakan tentang Allah di dalam surga, ia harus menggunakan bahasa metafora dan anthropomorphic agar pembaca dapat memahami. Ketika kita melihat tulisan yang menyatakan bahwa Tuhan berkata, memerintah, memanggil dan melihat, tentulah kita tidak serta merta menganggap bahwa Tuhan memiliki pita suara, mata dan bibir. Melainkan ini merupakan cara narator untuk menggambarkan Allah. Sehingga pengertian tersebut dapat membuat kita untuk memahami pula bahwa hari dan aspek-aspek lain di dalam narasi penciptaan tersebut juga digambarkan secara anthropomorphic. Di mana hari yang dinyatakan di dalam bahasa anthropomorphic inilah yang dapat dimengerti oleh manusia agar dapat meniru Sang Pencipta. ${ }^{73}$

Akan tetapi kita perlu sekali lagi mengkritisi pandangan tersebut dengan lebih teliti untuk langsung mendeskripsikan bagian tersebut hanya sebagai sesuatu yang sifatnya figuratif yang kemudian tidak benar-benar merujuk kepada aktifitas dan realitas Ilahi yang sesungguhnya. Karena sebenarnya frase "Tuhan berfirman" menyatakan tindakan Allah sesungguh-sungguhnya yang berdampak di dalam penggenapan kehendakNya. Sehingga ketika Allah berfirman "jadilah terang" maka terang pun jadi, di mana hal tersebut menyatakan tindakan Allah yang penuh kuasa dan berhasil. ${ }^{74}$ Seperti kemudian di dalam Kejadian 2:7, frase "Tuhan menghembuskan" mungkin dapat dimengerti di dalam terminologi anthropomorphic tetapi kata debu, tanah, manusia demikian juga nafas hidup haruslah dimengerti sebagai sesuatu yang nyata, dan penafsiran anthropomorphic pada bagian ini tidaklah secara sah dapat diaplikasikan.75 Demikian pula dengan 6 hari penciptaan bukanlah bahasa anthropomorphic

73 Bruce K. Waltke, dan Cathi J. Fredricks. Genesis: A Commentary (Grand Rapids: Zondervan, 2001), 77.

74 Young, Genesis, 56.

75 Ibid.,57. 
karena terminologi ini hanyalah dapat diterapkan kepada Allah. Sehingga ketika di dalam satu bagian perikop terdapat bahasa antopomorphic tidaklah semua bagian diterjemahkan juga seperti itu. ${ }^{76}$

\section{Argumentasi Terhadap Pendekatan IImu Pengetahuan}

Di dalam perdebatan ke-harfiah-an hari penciptaan, argumentasi dari kalangan para ilmuwan menjadi suatu faktor besar yang memengaruhi keabsahan penafsiran secara harfiah. Oleh karena itu, dalam bagian ini akan menyajikan beberapa data pembanding dari para ilmuwan yang percaya kepada penafsiran harfiah terhadap klaim-klaim yang menyatakan bahwa alam semesta dan bumi telah berusia sangat tua.

Pertama, argumentasi yang mencoba menolak pendekatan geologi yang menyatakan bahwa umur bumi telah sangat tua. Scott M. Huse kemudian mencoba mengangkat fakta-fakta yang menjadi anomali bagi kalangan yang menerima bahwa usia bumi telah sangat tua dari pendekatan geologi. Sebagai contoh, penemuan jejak kaki manusia dan dinosaurus yang berada bersebelahan dalam satu lapisan yang berjumlah sangat banyak di Mexico, New Mexico, Arizona, Missouri, Kentucky, Illinois dan beberapa lokasi di U.S. Penemuan ini biasanya disebabkan dari erosi akibat banjir ataupun karena bulldozer. Penemuan ini telah dipelajari dengan seksama dan diteliti oleh paleontology yang dapat diandalkan, di mana hasilnya tidaklah dapat dianggap sebagai penipuan. ${ }^{77}$ Memang di sisi lain tetap terdapat ilmuwan-ilmuwan yang meragukan fakta-fakta tersebut seperti Dr. Kitcher yang meragukan penemuan jejak kaki dinosaurus dengan jejak kaki manusia yang tidak lagi mudah untuk dibedakan di suangai Paluxy karena masalah pengaruh sejarah sosial manusia yang dalam masa-masa sulit beberapa penghuni setempat mencari uang dengan cara mengukir jejak

76 Ibid., 58.

77 Scott M. Huse, The Collapse of Evolution, 2nd ed. (Grand Rapids: Baker Book, 1993), 32-33. 
pada potongan-potongan batu-batuan. Bahkan ia mengatakan putra dari Henry Morris yang adalah anggota dari ICR terpaksa mengakui bahwa beberapa dari sisa bukti peninggalan adalah palsu. ${ }^{78}$ Namun, Dr. Kitcher hanya membesar-besarkan analisanya hanya berdasarkan sebagian bukti, sehingga analisa tersebut tidaklah valid, karena sebagian jejak kaki tersebut tetap dapat dibedakan dan John D. Morris memiliki kejujuran ilmiah dengan menolak aspek-aspek palsu dari bukti-bukti tersebut dan menerima buktibukti yang benar. ${ }^{79}$ Terlebih jejak kaki tersebut telah ditemukan sebelum masa depresi seperti yang telah salah diklaim oleh Dr. Kitcher dan pada akhirnya para ilmuwan yang menolak fakta tersebut secara sederhana karena mereka menganggap manusia tidak mungkin hidup sezaman dengan binatang dinosaurus. ${ }^{80}$

Kedua, Charles Darwin di dalam bukunya On the Origin of Species menekankan dua poin penting di dalam teorinya yakni universal common ancestry dan natural selection. Darwin berargumen bahwa semua makhluk organik yang pernah hidup di dalam dunia berasal dari bentuknya yang primitif sebelumnya. Ia melihat bahwa makhluk di dalam bentuk primitif tersebut dalam proses selama jutaan tahun berkembang menjadi bentukbentuk organisme yang berbeda-beda dan semakin kompleks seperti yang ada saat ini setelah jutaan generasi. Hal tersebut dapat tercapai dalam terjadinya proses natural selection, seperti tempat yang dalam beberapa generasi sangat dingin, dengan sendirinya menyeleksi hanya domba-domba berbulu tebal yang dapat bertahan hidup, dan dengan demikian terdapat hanya domba berbulu tebal. ${ }^{81}$

\footnotetext{
78 Jeff Hammond dan Charles Pallaghy. Alkitab \& Ilmu Pengetahuan (Jakarta: Yayasan Pekabaran Injil “Immanuel” 1992), 118.

79 Ibid.,118.

$80 \quad$ Ibid., 120.

81 Stephen C. Meyer, Darwin's Doubt: The Explosive Origin of Animal Life and the Case for Intelligent Design (New York: HarperOne, 2013), 3-6.
} 
Namun di akhir buku tersebut, Darwin menemukan beberapa fakta yang mengganggunya, di mana ia tidak dapat menjelaskan fakta terjadinya ledakan penemuan fosil di zaman Kambrium (Cambrian Explosion). Begitu banyak makhluk hidup yang sangat kompleks pada lapisan tersebut yang muncul secara "tiba-tiba" tanpa adanya bukti nenek moyang yang memiliki struktur yang lebih sederhana pada lapisan dibawahnya. Sehingga fakta munculnya begitu banyak binatang tersebut tidaklah sejalan dengan teori Darwin mengenai "gradual evolutionary change". Kesulitan tersebut juga telah dikonfirmasi oleh Louis Agassiz, seorang ahli paleontologist di jamannya sebagai kesulitan yang tidak mungkin dapat diatasi oleh teori Darwin. 82

Menyikapi hal tersebut Scott M. Huse, berdasarkan tidak adanya satupun fosil nenek moyang di dalam lapisan pre-cambrian, maka dengan jelas dapat dikatakan hal ini merupakan bukti bukan dari proses gradual organic evolution melainkan penciptaan yang bersifat supranatural. 83 Terlebih lagi, terdapat fakta yang menantang keberadaan teori natural selection, di mana variasi dalam skala kecil tidak menghasilkan perbedaan yang signifikan atau perbedaan spesies, akan tetapi bila dilakukan di dalam skala besar, maka hasilnya adalah kemandulan ataupun kematian. Sehingga variasi ekstrim antara binatang pasti akan mengalami degenerasi atau menjadi mandul. ${ }^{84}$ Sebagai contoh variasi skala kecil (micro-evolution) adalah terdapatnya lebih dari 200 variasi anjing. Sementara contoh variasi sekala besar (macro-evolution), tidaklah pernah terjadi, anjing tidak pernah menjadi kuda, dan bahkan ketika terjadi persilangan yang tidak normal maka akan selalu menghasilkan generasi yang mandul, seperti persilangan kuda dengan keledai menghasilkan mule yang mandul, atau persilangan zebra dengan kuda akan menghasilkan Zebronkey yang mandul dan persilangan

82 Ibid., 6-8.

83 Huse, The Collapse of Evolution, 54.

84 Meyer, Darwin's Doubt, 11. 
antara singa dan macan akan menghasilkan Liger yang mandul. ${ }^{85}$ Ironi yang sangat menarik di dalam usaha para evolutionist yang sedang ingin membuktikan teorinya adalah justru menyatakan teorinya salah dan pada saat yang bersamaan mengkorfirmasi kebenaran di dalam Alkitab yakni Tuhan menyatakan bahwa baik tanaman, burung, ikan dan binatang melata berkembang biak sesuai dengan jenisnya masing-masing (Kej. 1:11,12,21,24,25) bahkan dikonfirmasi pula di dalam Perjanjian Baru dalam 1 Korintus 15:38-39 “... Ia memberikan kepada tiap-tiap biji tubuhnya sendiri. Bukan semua daging sama: daging manusia lain dari pada daging binatang, lain dari pada daging burung, lain dari pada daging ikan". .86

\section{Kesimpulan}

Setelah kita membahas berbagai aspek terkait perdebatan pemahaman hari penciptaan, termasuk penggunaan kata hari di dalam Kejadian 1 yang dimengerti dalam pengertian siang dan penggunan kata hari pada frase, "jadilah petang dan jadilah pagi, itulah hari..." maka dengan yakin kita dapat katakan bahwa Alkitab menyatakan secara harfiah 6 hari penciptaan, dan bahkan termasuk hari yang ke 7 haruslah dimengerti secara harfiah dan juga tidak harfiah. Pandangan ini bukanlah pandangan baru melainkan sudah berakar sangat kuat di dalam tradisi penafsiran di sepanjang sejarah Yudaisme dan Kekristenan.

Sementara itu, pandangan tidak harfiah juga sudah berkembang di dalam sejarah penafsiran, akan tetapi isu penafsiran tidak harfiah menjadi kian menguat di dalam terang ilmu pengetahuan modern yang menyatakan bahwa umur bumi sudah sangat tua dan pada saat yang sama mengubah cara pandang penafsiran terhadap Kitab Kejadian di dalam narasi hari penciptaan. Gurney mengungkapkan begitu banyak orang Injili di dunia

\footnotetext{
85 Huse, The Collapse of Evolution, 55-56.

86 Ibid., 57.
} 
barat yang memikirkan ulang apa yang kelihatannya Alkitab nyatakan khususnya mengenai hari penciptaan harfiah yang diyakini kurang lebih 6000 tahun yang lalu, dan mengenai air bah yang terjadi secara global, karena pendekatan ilmiah mengatakan telah membuktikan teori evolusi dan usia alam semesta yang telah miliaran tahun. Sehingga pandangan tersebut kemudian menjadikan Alkitab tidak sedang memaksudkan apa yang kelihatannya Alkitab nyatakan. Peristiwa ini dipicu masa lalu di dalam kasus Galileo dan perdebatan mengenai heliosentris yang kemudian mengakibatkan mereka merasa takut untuk menolak teori evolusi dan umur bumi yang tua sehingga menciptakan beragam teori untuk mengharmonisasikan Alkitab dengan teori evolusi dan usia bumi yang tua. Diperparah mereka mencari bukti-bukti untuk meyakinkan bahwa Alkitab tidak sedang memaksudkan apa yang kelihatannya Alkitab nyatakan. ${ }^{87}$ Namun meskipun demikian, haruslah tetap kita memegang teguh apa yang memang Alkitab ungkapkan mengenai hari penciptaan sembari terus menyadari adanya limitasi yang besar bagi manusia untuk benar-benar dapat menyelami kebijaksanaan dan kebesaran Allah di dalam penciptaan.

87 Gurney, Six Day Creation, 11. 